conducting the fmnals of Philosophy for at least a year without any assistance of much consequence, but he has been agreeably disappointed.

He was shameless, indeed, this intrusive Scot of the "loyal town" in Strathearn, not very far from Bannock. burn, which perhaps explained it.

After all, however, he had some good men working with him, and he did not get what was apparently his wish-to write the whole Annals himself. There, for example, was Mr. John Dalton of Manchester, made famous some twenty years before by his discovery of colour-blindness ("Daltonism" it was called by Prevost, but this was objected to by the English chemists, who did not wish to "associate a great name with a physical defect"); he wrote several articles for the Annals (on respiration and animal heat, oxymuriate of lime, etc.). Dalton was indebted to Thomson, too, for the support he gave to his atomic theory; indeed, Thomson gave to the world (in 1807) the first detailed account of that theory, and in these very volumes of the Annals he was writing articles on his friend's theory which made it very widely known. Another writer was William Henry, M.D., also a chemist by inclination, although a physician by profession. He wrote articles on diabetic urine, on uric acid, on the eudiometer, etc. Then there were contributions from the pen of Berzelius of Stockholm (another M.D. with a love for chemistry which made him famous) on tise composition of unimal fluids, etc.; from William Prout, M.1., who took his degree in Edinhurgh a year before, and was "one of the pioneers of physiological chemistry," and from Alexander Marcet, M.D., physician ind chemical lecturer to Guy's Hospital, not to enumerate many others whose names have gained a place not only in the Annals of Philosophy, but also in the more exclusive Dictionary of National Biography. One cannot but be struck by the fact that Thomson gathered round him many distinguished men, even if he did say to himself abont the Aninals, "et quorum par's magna fui."

We must, not without regret, leave Thomas Thomson, as he walked out from Paternoster Row some evening early in December, 1813, carrying perhaps that month's part of the Annals under his arm, proudly conscions of having completed successfully the first year of his journal. "Thought I might have had to write the whole thing myself, perhaps, and I should have done it," we can imagine him saying; "would have done it," rather, for he came from the land where woulds and shoulds get mixed like the weather there. It may be that he was thinking of his old home Crieff, away in the north, far from this "b:ick Sahara" (as another philosopher from Scotland, the Sage of Chelsea, irreverently cal!ed London some years later), looking out on the long, rugged masses of the Grampians, snow-capped now, the month being December. It may be his thoughts stopped a little short of Crieff, at Stirling, where lived a certain maiden, to be ere long a chemist's bride. Possibly it was nothing half so romantic about which he thought, but only of the circulation of the Annals, and how it could be increased. But there he was, indubitably a strong man, with a marked leaning to chemistry, ruuning lis Annals, planning more work for 1814 , saying to himself "I will succeed" (it should have been "shall"), having (all unknown to him) sone forty years more of cheerful labour before him in Glasgow and elsewhere, and a resolute heart, an active brain, and a masterful spirit to carry him to his goal. Vale T. T.

I'He late Dr. Henry Franklin Parsons, formerly of the Local Govermment Board, left estate valued at £3,276.

IN the Nuova Antologia Generale-Medico Ferrero di Cavallerleone gives an account of the measures taken for the prevention of typhoid among the Italian troops in Tripoli. The General personally began to vaccinate the soldiers in August, 1912. Up to June, 1913, the total number of antityphoid vaccinations performed was 16,191 of these 6,691 were first, 5,427 second, and 4,068 third vaccinations. In the first of these groups there were 9 cases of enteric ferer with three deaths, the morbidity per 1,000 being 0.4 . In the second group there were also 9 cases, but no death, a morbidity of 1.65 per 1,000 . In the third group there were three cases. without a death, a morbidity of 0.49 per 1,000 . The morbidity during the same period among the non-vaccinated men in Tripoli was 35.3 and the mortality 7 per 1,000. Now antityphoid vaccination is bcing carried ont in all garrisons in Tripoli.

\section{THE UNIVERSITY OF LONDON.}

By E. Gr.h.im Littice, M.D., F.R.C.P.,

MEMBER OF THE SENATE OF THE UNIVERSITY.

The Faculty of Medicine of the University of London on December 1st passed a number of resolutions endorsing the action of their Board of the Faculty. The question of the constitution of the Faculty which will result from the recommendations of the recent Royal Commission did not come under consideration, and we are promised another report from the Board on this subject before Christmas. As I believe this matter to be of primary importance to all the Schools of Medicine as well as to the University, and as I am convinced the members of the present Faculty of Medicine are living in a fool's paradise if they think they can blissfully ignore the Commission and all its works, I shall be grateful if you will allow me to put some matters before my fellow. members of the Faculty which I think they may not havo thought ont fully.

The references to pages and sections are to the Final Report of the Royal Commission on University Education in London (Cd. 6717, price 2s.).

The term "Schools" means throughout those teaching bodies which elect to qualify as Schools of the University but do not, or cannot, elect to become Constituent Col. leges. The latter term is restricted to the use made of it by the Commissioners - namely, to indicate those teaching: bodies which elect " to transfer" all educational and finan. cial control of their affairs to the University" (Section 119). In medicine there "cannot be more than threo such colleges," but the full scheme will come into forco when one such college has been established (Section 298). The list of Schools contemplated in the Faculty of Medicine is given on page 204, and includes all the present teaching schools, but these will have to appoint University representatives, chosen by the Academic Conncil, on their governing bodies, and generally submit to a far larger degree of University control than any to which they havo hither'to been accustomed.

The measure of control contemplated by the Report may be gauged from the following statements:

The University must be satisfied that there is no adequate and suitable provision of University instruction already existing in the locality concerned for the particular class of students whom it is proposed to teach, and it must have the power to require the co-ordination of the work of the centre with the work existing elsewhere as a condition of its continued status as a School (p. 203).

Thus it is evident that the Uuiversity may bring pressure to bear upon certain of the present suliools to forego some of their courses of study and thus seriously interfere with their internal government.

In the case of a Hospital medical school . . . the Governing Body of the Hospital will appoint a cornmittee of its own members, with the additional of University representatives, to conduct the business of the School and will always invite and receirc a report from that committee before deciding any matter affecting that department of the institution (p. 203)

Even in the case of teachers not appointed by the University and for whom no Cniversity title is desired the Seunte will have some voice in the appointments, for example, by representation on the appointing committee (p. 203).

The Faculty of Medicine as it at present exists is to be abolished, and no other Faculty will be constituted until the establishment of the Constituent College or Colleges. Until the new Faculty is so constituted, the new "Board of Studies in Mediciue" will form the unit of Government of the Schools, and this Board will report directly to the Senate (section 384). When the New Faculty comes into existence, the Board will not have the right of direct access to the Senate, but will have to report to the Faculty.

The constitution which the Report proposes for the Schools, not being Constituent Colleges, is as follows. The Board of Studies in Medicine shall form a committee of itself, subject to the approval of the Senate, to prepare Curricula and Syllabuses, etc. This Committee shall report to the parent Board of Studies; the Board of Studies shall in turn report to the Faculty of Medicine, which when constituted shall consist of the "University Professors and other Teachers of standing in the University Medical Colleges which would be Constituent Colleges." "Some eminent member's of the profession who were not 
teachers in these colleges" might be co-opted, but this right must "be sparingly exercised," and need not be exercised at all. (Section 305.)

The powers of the Faculty thus constituted are detailed on page 53. It shall have the power generally "to deternine the conditions for the award of degrees, diplomas, and the ccurse of study to be pursued by students of the University within the Faculty."

'The Faculty will report to the Academic Council, which will consist of the Deans of the Faculties, and eight other members of the Faculties, clected in common session. The Vice-Chancellor is ex officio chairman; with this exception all the members, we may be sure, will be members of the Constituent Colleges. The Academic Council will have large executive powers in educational matters, includ. ing the recognition and visitation and University control of Schools.

The Academi Council reports to the Senate, on which it has two representatives out of fifteen members. The Senate transmits its instructions to the Schools through a special committee to be appointed by the Senate (Section 400). This committee is " to supervise curricula and general examinations in the Schools," but "it is not to be constituted so as to represent institutions or particular classes of students." This committee, which I shall call for short the "Scholastic Council," though it is not given any distinguishing name in the Report, is comparable to the Academic Council, in that in those branches of study in which there are no Faculties this Committee receives reports which, it there were a Faculty, would be trans. mitted to the Academic Council. The Scholastic Council might very well be strengthened so as to perform for the Schools the functions which the Academic Council per. forms for the Constituent Colleges. The Scholastic Council communicates its findings to the Board of Studies, which I have called the "unit of yovernment of the Schools." (It must be carefully borne in mind that the meaning given by the Report to the term "Board of studies" differs from the meaning which that term has liad in the past.)

The constitution of all the bodies concerned makes the procedure very inconveuient and unfair for the Schools, as compared with the procedure which is to bs adopted for the Constituent Colleges.

The Board of Studies is to consist (Section 384) of the "principal teachers in the Schools of the University"; it is therefore entirely comparable to the constitution of the New Faculty, which will consist of the Professors, Readers, and some Co-opted Teachers of the Constituent Colleges; but whereas the Faculty, consisting of Teachers at the Constituent Colleges, reports direct to the Academic Council, also consisting of 'Teachers at the same Colleges, the Board of Studies reports direct to the Faculty-that is, to a body of persons with a direct financial and personal interest in hustening the transfer of all students for Oxford, Cambridge, or London degrees from the Schools to the Constituent Colleges.

As the statement I have italicized has been questioned, perhaps I may be allowed to substantiate it. It must be remembered that the Commissioners allowed the Professor i limited amount of privato practice, but they did not mention the means by which limitation could be enforced. In many branches of medicine it is obviously impossible to fix the hours during which the professor may respond to the calls of his patients. A man with appendicitis, a woman in labour, a child with a doubtful diphtheritic throat, cannot await the convenience of the surgeon, the obstetrician, and the physician respectively. Limitation could not, in fact, be enforced, and this consideration influenced the Board of the Faculty in the unanimous vote which they recorded that the Professor should not be allowed any practice at all. But the Commission's recommendation holds the field, and while it does so it is obvious that it is to the Professor's pecuniary interest to attract as many students as possible to his classes. The prestige of the college and of its teachers will to a large extent depend on the number of students which attend it.

As the Dean of the Faculty of Medicine very pertinently observed, the Commissioners make a division where no division existed before. University students studying at the Colleges are to be sharply differentiated from University students studying at the Schools; they are to be branded as separate even after thoy have graduated; for graduates are required to add to their degree the name of the College or School at which they studied. The cum. brous and absurd titles which will result from this regu'a. tion do not seem to have touched any sense of humour in the Commissioner's.

But the dualism which the Commissioners introduce is not even a fair dualism, for the dice are heavily loaded in favour of the Constituent College and against the Scliool. I have shown how the constitution favours tho College. But another most important privilege is reserred for teachers in the Colleges and is not accorded to teachers in the Schools, in that the teachers at the Colleges examine their own students; but this is not the case with teachers at the Schools. For example, if three colleges, A, B, C, are constituted, the examinations are differentiated at $A, B$, and $C$ respectively. But if $X, Y, Z$ are Schools of the University, the same examination must be taken by each of these individual schools; that is, the teachers will not cxamine their own students. Moreover, the examination held at the Schools will be controlled by the Faculty, and the Academic Council, that is by the teachers at the Constituent Colleges.

The President of the Board of Education has clearly indicated that when a bill has been submitted by tho Departmental Committee at present sitting, the bill will be made a Government measure, and will presumably be backed by the present coalition majority. It may then be asked, "What is the use of kicking against the pricks?" and it may be questioned whether the present Faculty of Medicine can do anything to save the situation. I believe that it can, but not without combination with other Faculties and not without exerting itself to the vtmost.

There is a proposal now being discussed in other Faculties, and notably in the Faculties of Arts and Science, by which, if the Report of the Commission is pushed, certain modifications may be obtained which will remedy to some degree the more glaring injustices of the changes recommended by the Report. My chief purpose in writing this communication is to lay before your readers the modification suggested. To put it as brietly as possible, the Faculty is urged to demand that the privilege of reporting direct to the senate, through the special committee to bc appointed by that Body, which I have called the "Scholastic Council," shall be retained permanently, and shall not be given up, as the Report suggests, when the New Faculty of Medicine comes to be constituted.

The effect of this modification will be best understood by reference to the diagram (p. 1499). Scleme I represents the proposal of the Commissioners which will come into operation as soon as a Constituent College, and thereby the new Faculty, comes into being. By this scheme any report from the Board of Studies must be submitted to the Faculty, and this report follows the course indicated by the arrows in the diagram, until the instructions of the Senate come back to the Board of Studies via the "Scholastic Council." As the "control of the teaching and examining work of the University should as far" as possible rest with the Faculties" and "only the control of finance and administrative business rest with the Senate" it is obvious that in most cases affecting the Schools the Senate will do little more than transmit the judgements passed by the Faculty and Academic Council. It is surely unjust to require that " the principal teachers in the Schools" shall have to submit, in all their arrangements for teaching and examining their own students, to revision by a body of competing teachers of no higher status than themselves, but who happen to be teachers in a Con. stituent College. 'The scliome marked II represents the procedure which the Commission recommends as provisional until the new Faculty is established. By this scheme the Schools have direct access to the Senate via the "Scholastic Council," and the proposal to which I am inviting the attention of the present Faculty is that when the Constituent College and the new Faculty make their appearance, the affairs of the Constituent College shall be managed by the Faculty and Academic Council (subject to the final authority of the Senate), and the affairs of the Schools shall te managed by the Board of Studies and the Scholastic Council, which should be strengthened by representation from the Schools in the same measure as the Colleges are represented on the Acadernic Council The "Scholastic Council " will be to the same degree under the authority of the Senate, and this Council should hare the 
same represcatation on tho Senate as the Report concedes to the Academic Council. The subordination of the Schools to the Colleges which is contemplated in the Report thus disappears. If it is thought adrisable to have contact between the Schools and Colleges, this might be arranged by the common session of the Committees of the Faculty and of the Board of Studies (indicated in the diagram by the double-pointed arrow, $\mathrm{s})$. This would mean an interchange of views on an equal basis; and the common outlook thus obtained would usefully leaven both the parent bodies to which these Committees report. If it be objected-and the objection has been made-that this is to separate the Colleges and the Schools into watertight compartments, the answer is that the Commission has so decreed it, and it is useless to attempt to override their

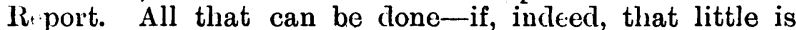
possible-is to correct the most obvious inequalities; and I repeat that it is only by concerted action by as many Faculties as may be practicable that even this may be achieved.
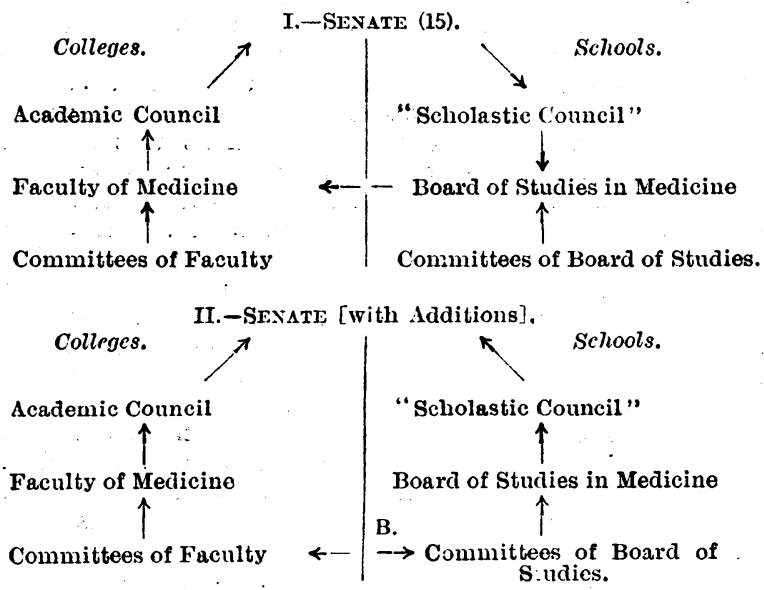

\section{SCIENCE NOTES.}

Carnotite, a yellow mineral found in sandstone in Western Colorado, would appear to have become one of the chief sources of radium. It occurs usually as light yellow specks disseminated through the sandstone or as yellow incrustations in the cracks or pockets. It appears from an article in Science of October 3lst that the carnotite so far obtained in Colorado has been exported to Germany or France, and that the price of radium has been fixed by the European manufacturers. A National Radium Institute has now been formed to work in association with the Bureau of Mines at Denver, Colorado, and the technical operations will be guided by the scientific staff of the bureau. Carnotite is a hydrated vanadate of uranium and potassium, and $\mathrm{h}$; institute proposes not only to collect radium, but also to study the separation of uranium and vanadium. All processes, such as the details of apparatus and plant, will be published for the pablic benefit, the main object of the institute being to procure enough radium to conduct extensive experiments in radium-therapy, with special reference to the treatment of cancer; chemical and physical inrestigation will be carried out also. Professor Soddy, in commenting on this scheme in Nature of last week, expresses the opinion that apparently the question of the supply of radium, in whatever country it is found, will be regarded more and nore as of national importance, and that a nation trusting to the equitab e operations of the laws of supply and demand is likely to be squeezed out. He therefore considers it to be a matter of public interest to this country, and that it should be lifted once-for all above the plane of private venture and financial speculation. $\mathrm{He}$ appeals to the Institution of Mining and Met.lllurgy in this country to appoint an expert committee mainly of practical mining authorities, but with representatives of technical chemistry and medicine, to consider the situation and take energetic steps to meet it.

It having been shown that the serum of normal dogs contains a ferment capable of splitting up a peptone prepared from dogs' muscle tissues, experments were extended by-
Pincussohn and Petow (Biochem. Zcitschr., Octobci 28th, 1913) to other animal sciurus to see if animals possessed in their serum specific ferments to their own tissue-peptones. Abrlerhalden has very successfully demonstrated that in pregnancy there is a ferment action claborated against the proteins and poptones of the placenta, and the practical application of his finclings is now well known. He has used two methods, one, the dialysation method for the demonstration of proteolytic action of the pregnant serum, and the second, the optical method for its peptolytic power. The "guardian ferments," as they have been called, obtained by these methods are probably not identical ; they do not correspond, for example, to trypsin, which has, combined in itself, both a proteolytic and a peptolytic power. Observers have noted a discrepancy between the two methods. In general, normal serum does not degrade organ protein. It must be assumed that within the body useless protein, that is, from functionless cells, must somelow bo degraded through peptones to amino acids, but this is probably brouglit about by an inherent autolytic property in the cells. The blood acts as a vehicle not merely for free amino acids, but in all probability also for larger complexes, and it would seem reasouable to imagine that there ust normally be guardian ferments capable of converting possibly harmful complexes into innocuous iractions. The authors hare attempted with success to disconve $r$ whether the normal serum of animals of certain species have the power of breaking up peptones from organs of that particular species in a specific manner. They employed peptones obtained by partial hydrolysis with sulphuric acid from the musele tissues previously washed quite free from blood, and the ferment action of the tested serum was indicated by the rotation observed in the polariscope. It was found that the serum of various animals acted only on peptones of the particular species, but not on those of foreign species, and that no action was called forth in the case of wore completely hydrolysed or indifferent peptones. It was noted, however, that dogs' serum degraded the pep. tone derived from fox muscle, and vicu versa, and, from other indications also, it was clear that generic relation ships of animals were reflected in the action of their peptolytic ferments. One very striking and important phenomenon was brought to light, namely, that the blood serum of normal guinea-pigs has a general peptolytic power, as Abderhalden had previously hinted, for it was found that this animal's serum acted on peptones derived from other species, and if further investigations support this observation, we shall have to consider whether guinea-pig's serum contains a plurality of ferments or a universal ferment against different peptones. In practical work on immunity we employ mostly (almost exclusively) guinea-pig sernm as a source of complement, and the question of plurality of complements is an old battle-ground. The experiments lend support to the view that serum complement and serum ferment have much, if not all, in common; and it will be safe to predict that the observations of the authors will stimulate further research into the question.

Human milk, on chemical analysis, differs in three important ways from cow's milk: It contains much more lactose and much less protein and a greater percentage of substances of an unknown nature with little or no nitrogen in their composition. Meigs and Marsh (Journal of Biological Chemistr!!, October, 1913) have investigated these differences. Before any comparison of the two kinds of milk can be made it must be borne in mind that the composition of milk varies according to the period of lactation, and thus average figures are unsatisfactory. They find that from the beginning of the second month of lactation onwards the limits of normal variation are, for liuman milk, 2 to 4 per cent. fat, 6 to 7.5 per cent. lactose, and 0.7 to 15 per cent. protein; and for cow's milk 2 to 4 per cent. fat, 3.5 to 5 per cent. lactose, and 2.5 to 4 per cent. protein. These figures represent percentages of whole milk. With regard to the other constituents of both, the chemical nature of which is as yet unkuown, they appear to be important constituents of diet. They contain little or. no nitrogen, and are soluble in alcohol and ether. They are in greater abundance in human milk during the early periods. of lactation, and gradually diminish as lactation progresses. 'Thus, in the 